\author{
Beata Pituła \\ Silesian University of Technology (Poland) \\ ORCID: 0000-0002-7691-3821 \\ e-mail: beata.pitula@polsl.pl
}

\title{
The Teacher and the Idea of Society 5.0 - Initial Diagnosis of the Problem
}

\begin{abstract}
The primary aim of this article is to present the results and research findings of a pilot study on teachers' attitudes manifested toward the idea of society 5.0. The study is a part of one of the priority research areas of the Silesian University of Technology - Processes automation and Industry 4.0. in terms of the socio-cultural and methodological implications of Industry 4.0. Eighty-four teachers participated in the research and completed the questionnaire electronically. The research bores the characteristics of a preliminary diagnosis of the problem. Hence, the collected empirical material does not allow the formulation of methodologically valid conclusions. However, it may constitute a "voice in the discussion" on the preparation of teachers for the inevitable change of the role of the school and the teacher in the new society.
\end{abstract}

Keywords: teacher, attitude, society 5.0

\section{Introduction}

The world is constantly changing under the influence of new technologies, new economic solutions, and a new geopolitical system, implying, and in part forcing, changes in its assessment and thinking about it. The dynamics of these changes is accelerating from decade to decade. Adaptating to them requires more openness, creativity, and innovation in human actions (Tworóg \& Mieczkowski, 2019, p. 26). New opportunities are, as always, new challenges, the necessity to overcome barriers and difficulties, search for new solutions that are more suited to social needs, and a chance for a better life. It is essential to use the opportunities created by new technologies properly to maintain economic growth, but above all, create conditions for a qualitatively better, fully satisfying life (Tworóg \& Mieczkowski, 2019, pp. 28-30). The whole usage of the enormous opportunities created by the development of digital 
technologies such as the Internet of Things (IoT), Artificial Intelligence (AI), and robotics requires many different skills in the field of creating new relationships between humans and technology, i.e., simultaneously functioning in the real and virtual world. It means the necessity to eliminate the mental dichotomy between the two worlds and abandon their mutual opposition in favor of their mutualization (Harayama, 2017). Moreover, the implementation of these plans will be fostered by harmonious, targeted, joint action of various stakeholders, allowing for implementing a shared vision of the future (du Vall, 2019, p. 12).

This new, better vision of the world is built based on the ideas of the 5.0 society (born in Japan). It responds to the social challenges that this country has to face. The main ones include the demographic problem (a decreasing number of births and a growing number of older people) and the resulting increase in social security costs. Another one is the need to secure growing funds for infrastructure maintenance (du Vall, 2019, p. 23). It is not difficult to notice that the number of countries with similar problems is increasing every year. Hence, in 2015, the 70 ${ }^{\text {th }}$ Session of the United Nations General Assembly adopted the 2030 Agenda for Sustainable Development (Polski Komitet ds. UNESCO, 2015). It indicated 17 sustainable development goals and guaranteeing their implementation, and created a comprehensive system of international cooperation, the cardinal principle of which is peace and prosperity for all people of the entire planet. These goals are dedicated to society 5.0, which is super intelligent and will integrate cyberspace with the real world. It will entail the satisfaction of the individual's needs (regardless of age, gender, language, or any other limitations) at any time and, consequently, will build the prosperity of the global community (du Vall, 2019, p. 13).

The first step in creating society 5.0. is therefore forming and integrating with the international cooperation network creating innovations. The second step is full use of all the available data (big data) generated by various systems and coordination of their work, which will help search for optimal solutions to social, economic, and other problems. The third one is to strengthen cross-sectoral cooperation for co-creating and sharing knowledge and information available to everybody. All this is accompanied by socially responsible science, innovative research, and broadly understood social dialogue (du Vall, 2019, p. 28).

On the one hand, this concept seems to be worth pondering over, considering the pressing problems of the modern world, such as the aging of societies, hunger, poverty, and discrimination. On the other hand, given the rapid evolution of industry 4.0, it is inevitable. Therefore, it requires a vast educational effort to prepare society for its coming properly. Hence, the question is to what extent teachers (initiators, animators, but also change implementers) are prepared to take up this challenge? Do they need help, and to what extent? What do they know about society 5.0? Do they take any actions? If yes, what actions do they take to shape the digital and media competences of their students? There are many questions, but one needs to answer at least a few to build a support system based on these findings, to be able to introduce them rationally, wisely, and minimizing the psychological costs of changes. In the author's intention, the presented empirical material is the basis for specifying at least partial answers to these and other questions. 


\section{Methodological Concept of Research}

The theoretical basis of the research are three concepts: cognitivism, the theory of social learning, and the transtheoretical model of change. In terms presented by Jerome Brunner, Cognitivism assumes that human perception is determined by needs and values and is not something that appears immediately but is a form of information processing that includes two elements: interpretation and choice. Thus, how people react/act depends on their understanding/interpretation of the world. In the educational process, a person is not and should not be reduced to a subject receiving knowledge, but motivated to actively discover it, because information flowing to them from outside undergoes in mind a complex process leading to the understanding of a fact/event, i.e., giving them individual and subjective significance. According to this theory, the teacher only provides a kind of "scaffolding" for building the newly discovered knowledge by the student. "The scaffolding" is a set of guidelines and activities supporting the student, allowing them to acquire knowledge, develop various skills and attitudes necessary to cope with the challenges of life. "The scaffolding" is therefore not a restraining "corset" but a flexible "pad", the use of which, without consequences, can be abandoned at the moment when the necessary skills and attitudes become a fact and will constitute a "step" for further stages of development. According to this concept, the teacher is a kind of instructor, guide, and trainer on the path of personal development. This concept has become the starting point for the educational theories promoted today, such as constructivism or connectivism, recognizing the individuality and uniqueness of knowledge processing by an individual, perception of knowledge in the social and cultural context, human activity, and reflectiveness as a necessary condition for creating one's reality and expanding knowledge about the world; concepts that emphasize the need to redefine the functions and tasks of the teacher, orienting their work toward being a leader, guiding the student through the "labyrinths of knowledge", and helping them to overcome the problems of redundancy and the different value of omnipresent information.

It seems, therefore, that the teacher's consent to adopt a new (one might say consistent with the postulates of constructivism) personalizing view of the educational process is the basic condition for making changes in thinking about their educational practice, searching for innovative solutions, and their implementation. It is also a constitutive element in implementing the role of the model by the teacher for their students. The role assigned to them by the theory of social learning (Wojciszke, 2011,pp.397-398) explains the mechanisms of imitation and modeling, leading to the acquisition new behaviors by students, their maintenance, change, and disappearance. Therefore, it can be assumed that the functioning of the teacher as a spokesman or opponent of the idea of society 5.0 will largely shape positive or negative attitudes of students as citizens of that society. Whether and to what extent teachers are optimistic about the changes - the new society is, after all, a new challenge for educational practice - has been explained using the transtheoretical model of change, which assumes that when a person comes to change, they go through five or six stages of 
change functioning in the space of a circle. People can go through a stage multiple times before the change is sustained - the behavior stabilizes. The starting point for initiating the change is not fully conscious, but it is a sensed need for change (the so-called initial contemplation). A full realization of the problem regarding change and its consequences moves to the second stage called contemplation. It is the stage of reflection on whether such a change is beneficial, necessary, and worth the effort. Stage three - the preparation phase, deciding whether that change is necessary and worthwhile, and defining an action plan. Stage four - the action phase, i.e., the implementation of the assigned tasks. Stage five - maintaining activities aimed at achieving the goal. Therefore, reaching the final effect in the form of making and consolidating the change requires systematic, rational actions to prepare students to take advantage of the opportunities offered by modern technologies, modern media, i.e., a new reality.

When undertaking the research, it was assumed that the teachers' attitudes fundamentally determine the level of their activity and involvement in preparing students to build society 5.0, functioning in it, and making optimal use of the opportunities created by industry 4.0. At the same time, by attitude, I mean, as social psychologists do, a "learned, relatively constant tendency to positively or negatively evaluate a person, concept or object" (Zimbardo, 1999, p. 734). This attitude can be both an emotional or more or less balanced assessment of the object. They are defined on a continuum from negative to positive (full acceptance of the object) (Wojciszke, 2000).

In line with the adopted pattern of quantitative research, the main diagnostic goal of the research was formulated, which is to recognize the emotional-volitional and intellectual attitude of the surveyed teachers to the idea of society 5.0.

Its operationalization includes specific objectives, allowing to obtain knowledge about the material orientation of the respondents regarding the model of society 5.0; its evaluation, acceptance or disapproval of the idea, readiness to take action to implement the vision of the analyzed concept, and evaluation of one's resources necessary to perform the tasks and - based on the collected empirical material - developing a programme of activities to support teachers.

The main problem was formulated as a question:

What is the attitude of teachers toward the idea of society 5.0 ?

It was made more concrete in specific problems:

1. What is the teachers' knowledge of the concept of society 5.0 ?

2. What is the degree of acceptance/disapproval of the teachers toward the idea of society 5.0 ?

3. Do the teachers express their readiness to participate in implementing the idea of society 5.0 , and to what extent?

4. What benefits or threats of building society 5.0. do they perceive?

5. How do they assess their competences concerning the requirement to prepare their students to function in the new society? 
The research uses the method of a diagnostic survey, and within its framework, the survey technique (due to the epidemiological status, conducted electronically). The statistical method was used to define the relationships and dependencies between the variables: gender, length of work experience, professional promotion degree, the teachers' knowledge about society 5.0, the benefits and risks of implementing the idea of society 5.0., and the role of the school and the teacher in the new society.

\section{Description of the Study Group}

Eighty-four teachers participated in the study. The group was dominated by women ( $n=$ $69 ; 82.1 \%)$, with a smaller number characteristic for the group of men $(n=15 ; 17.9 \%)$. Most of the respondents were in the age range of 36-45 $(n=36 ; 42.9 \%)$ or in the age range of $46-55(n=24 ; 28.6 \%)$. The smallest number of the respondents was in both younger age groups (respectively, for the group under 25: $n=12$; 14.3\%; for the 25-35 age group: $n=$ $12 ; 14.3 \%)$.

The data on the respondents' employment: the length of work experience, the subject taught, the degree of professional promotion, and the type of school in which the respondents worked are presented in Tables 1-4.

Table 1. Work experience - frequencies

\begin{tabular}{lrc}
\hline Work experience [years] & $\boldsymbol{n}$ & Percentage \\
\hline$<5$ & 12 & 14,3 \\
\hline $5-10$ & 9 & 10,7 \\
\hline $11-20$ & 33 & 39,3 \\
\hline $21-30$ & 27 & 32,1 \\
\hline 31 and more & 3 & 3,6 \\
\hline
\end{tabular}

Based on the collected data, it can be concluded that with regard to the length of work experience, the teachers who worked between $11-20$ years $(n=33 ; 39.3 \%)$ and those who worked 21-30 years $(n=27 ; 32,1 \%)$ dominated. The smallest number of teachers were the teachers with relatively long professional experience (31 and more years: $n=3 ; 3.6 \%$ ).

Table 2. Subject taught - frequencies

\begin{tabular}{lcc}
\hline Subject taught - frequencies & $\boldsymbol{n}$ & Percentage \\
\hline Humanities, languages, social studies & 72 & 85,7 \\
\hline Technical and vocational subjects & 9 & 10,7 \\
\hline Physical education & 3 & 3,6 \\
\hline
\end{tabular}

Assuming the taught subject criterion, the group was dominated by the teachers of humanities, languages, and social sciences, who constituted as much as $85.7 \%$ of the studied 
group ( $n=72$ ). Much fewer, because $10.7 \%$ of the surveyed teachers, declared teaching technical and vocational subjects $(n=9)$. Only $3.6 \%$ of the surveyed teachers taught physical education $(n=3)$.

Table 3. The degree of professional promotion - frequencies

\begin{tabular}{lcc}
\hline The degree of professional promotion & $\boldsymbol{n}$ & Percentage \\
\hline Trainee & 12 & 14,3 \\
\hline Contract teacher & 12 & 14,3 \\
\hline Appointed teacher & 21 & 25,0 \\
\hline Diploma teacher & 39 & 46,4 \\
\hline
\end{tabular}

With regard to the degree of professional promotion, the group was dominated by diploma teachers $(n=39 ; 46.4 \%)$ and appointed teachers $(n=21 ; 25.0 \%)$. The study also included trainee and contract teachers - each of the mentioned groups accounted for $14.3 \%$ of the total results (for both groups: $n=12$ ).

Table 4. School type where the teachers worked

\begin{tabular}{llc}
\hline School type & $\boldsymbol{n}$ & Percentage \\
\hline Primary school & 54 & 64,3 \\
\hline Technical school & 12 & 14,3 \\
\hline Secondary school & 18 & 21,4 \\
\hline
\end{tabular}

As many as $64.3 \%$ of the study group were primary school teachers $(n=54)$. The rest of the groups were teachers employed in secondary schools - teachers of general secondary schools constituted $21.4 \%$ of the group $(n=18)$, and technical school teachers $-14.3 \%$ of the group $(n=12)$.

The analysis of the metrics data allows the conclusion that the studied group reflects the employment structure of teachers in Poland.

\section{Society 5.0 Image Reconstruction Based on the Knowledge of the Surveyed Teachers}

\section{Knowledge of the term "society 5.0" by the respondents}

Most of the respondents indicated that they had not encountered the notion of society 5.0 so far $(\mathrm{n}=72 ; 85.7 \%)$. The relationships between gender, age, length of work experience, professional promotion degree, and the knowledge of this concept are presented in Table 5. Due to the qualitative nature of the analyzed data, the Pearson chi square test was used for this purpose. 
Table 5. Relationships between gender, age, length of work experience, degree of professional promotion, and the knowledge of the notion of society 5.0 - Pearson's chi square test

\begin{tabular}{lrrrr}
\hline Gender x knowledge of the notion & 3,04 & 1 & 0,081 & 0,19 \\
\hline Age x knowledge of the notion & 10,50 & 3 & 0,015 & 0,35 \\
\hline Work experience x knowledge of the notion & 7,28 & 4 & 0,122 & 0,29 \\
\hline Professional promotion degree x knowledge of the notion & 8,01 & 3 & 0,046 & 0,31 \\
\hline
\end{tabular}

Knowledge of the concept of society 5.0 was related to age. This relationship was of moderate strength. The analysis showed that this concept was more often known to people from the middle-aged groups (25-35 years and 36-45) and much less often - to people from the youngest and oldest age groups. The knowledge of this concept was also associated with the degree of professional promotion. The strength of the relationship, in this case, was also moderate. The contract and appointed teachers encountered this concept more often and less frequently - the trainee and diploma teachers.

The respondents who knew this concept most often indicated that they learned it on the Internet $(n=6 ; 50.0 \%)$. Less frequently, however, they indicated that they had heard this concept on television or at scientific and thematic conferences (for each group: $n=3 ; 25.0 \%$ ).

Referring to the noticed dependence, knowing the concept by the teachers from the so-called middle age groups seems obvious just as the ignorance of it by the oldest teachers, while the declaration of ignorance in the youngest age group is surprising.

\section{Associations of the Respondents with the Term "Society 5.0"}

Responses to the question about the respondents' associations related to the notion of society 5.0 are presented in Table 6 .

Table 6. Associations with the notion of society 5.0 - frequencies

\begin{tabular}{lcc}
\hline Response & $\boldsymbol{n}$ & Percentage \\
\hline 5G network & 3 & 3,6 \\
\hline Digital society & 36 & 42,9 \\
\hline Super intelligent society & 12 & 14,3 \\
\hline Virtual reality & 21 & 25,0 \\
\hline I have no associations & 12 & 14,3 \\
\hline
\end{tabular}

The respondents most often pointed out that society 5.0 is associated with the digital society $(n=36 ; 42.9 \%)$ and virtual reality $(n=21 ; 25.0 \%)$. Less frequently, they identified society 5.0 with a super-intelligent society $(n=12 ; 14.3 \%)$. Only a small part of the group associated society 5.0 with the $5 \mathrm{G}$ network $(n=3 ; 3.6 \%)$. However, some of the respondents did not indicate any specific association they would have with the concept of society 5.0 $(n=12 ; 14.3 \%)$. 
The results allow stating that the number and content of the associations presented by the teachers are superficial, confirming the credibility of the declaration of the lack of knowledge about society 5.0.

Table 7. Relations between gender, age, length of work experience, degree of professional promotion, and associations with the notion of society 5.0 - Pearson's chi square test

\begin{tabular}{lcccc}
\hline & $\chi^{2}$ & $d f$ & $p$ & Cramér's $\boldsymbol{V}$ \\
\hline Gender $x$ associations & 11,93 & 4 & 0,018 & 0,38 \\
\hline Age $x$ associations & 36,46 & 12 & $<0,001$ & 0,38 \\
\hline Work experience $x$ associations & 41,80 & 16 & $<0,001$ & 0,35 \\
\hline Professional promotion degree $x$ associations & 21,09 & 12 & 0,049 & 0,29 \\
\hline
\end{tabular}

These associations were related to gender, age, length of work experience, and the degree of professional promotion (Table 7).

The analysis of the relationship between associations with the concept and gender indicated that women more often indicated a connection with the $5 \mathrm{G}$ network, digital society, and virtual reality. On the other hand, men more often chose the answer suggesting that they do not associate this concept with anything. The relationship between associations with the concept and gender was moderate in strength.

Regarding the relationship with age, the youngest age group more often indicated that they did not associate the term with anything. The teachers in the two middle-age groups (25-35 and 36-45) more often identified the notion of society 5.0 with a digital or superintelligent society. The respondents from the oldest age group more often associated this concept with the $5 \mathrm{G}$ network and the digital society. The strength of the association between age and associations was moderate.

The same pattern of dependence was observed concerning the length of work experience. The youngest group more often indicated that they did not associate this concept with anything. The teachers in the middle two groups more often identified the notion of society 5.0 with a digital or super-intelligent society. The respondents with the most extended work experience in the group more often associated this concept with the $5 \mathrm{G}$ network and the digital society. The strength of the relationship between work experience and associations was moderate.

With regard to the relationship between the degree of professional promotion and associations, it was found that the trainee teachers more often did not associate the concept of society 5.0 with anything. The appointed teachers more often identified this concept with the digital or super-intelligent society. The diploma teachers more often associated this concept with the $5 \mathrm{G}$ network and the digital society. The relationship between the degree of professional promotion and associations was weak.

Also, the answers to this question confirmed the relationship between associations about society 5.0. and the age of the respondents. Similarly to the previous analyzes, it is surprising that the youngest teachers did not have them. 


\section{Knowledge of the Respondents about Society 5.0}

When asked to evaluate their knowledge about society 5.0, the respondents indicated, on average, a small scope $(M=2.00 ; S D=1.04)$. There were no differences between men and women here - the Mann-Whitney U test used to compare the two groups (due to the disproportion in numbers in the compared groups and the ordinal nature of the measurement scale on which the knowledge of the concept was measured) was not statistically significant: $W=616,50 ; p=0.223 ; r b s=0.19$.

However, differences between age groups were found in this aspect - the Kruskal-Wallis test was statistically significant: $\chi^{2}(3)=17.00 ; p<0.001$. Persons aged $25-35$ assessed their level of knowledge the highest: $M=2.75 ; 95 \% C I$ [2.21;3.30]. The lowest level of knowledge was indicated by persons from two extreme age groups - the youngest: $M=1.50 ; 95 \% C I$ [0.96; 2.05]; and the oldest one: $M=1.50 ; 95 \% C I[1.12 ; 1.89]$.

There were also differences in the knowledge of society 5.0 between the groups distinguished according to the degree of professional promotion - also, in this case, the KruskalWallis test was statistically significant: $\chi^{2}(3)=25.72 ; p<0.001$. The appointed teachers rated their level of knowledge the highest: $M=2.86 ; 95 \% C I$ [2.47; 3.25]. The trainees indicated the lowest level of knowledge: $M=1.50$; $95 \% C I$ [0.98; 2.02]; and the diploma teachers: $M$ $=1.62 ; 95 \%$ CI $[1.33 ; 1.90]$.

The length of work experience analysis could not be performed due to the zero variance in the knowledge about society 5.0 assessments in the comparative groups.

\section{Competences Required of Teachers in Society 5.0 in the Opinion of the Respondents}

The teachers provided different answers to the question of what competencies society 5.0 requires of them (as teachers). The answers to this question are presented in Table 8.

Table 8. Competences required of teachers in society 5.0 - frequencies

\begin{tabular}{lcc}
\hline Response & $\boldsymbol{n}$ & Percentage \\
\hline Ability to learn quickly & 8 & 9,5 \\
\hline $\begin{array}{l}\text { Innovation, unconventional and adaptive } \\
\text { thinking }\end{array}$ & 33 & 39,3 \\
\hline Readiness for continuous learning & 12 & 14,3 \\
\hline $\begin{array}{l}\text { Ability to search for reliable and necessary } \\
\text { information, to analyze and verify it }\end{array}$ & 16 & 19,0 \\
\hline $\begin{array}{l}\text { Independence and flexibility in thinking and } \\
\text { acting }\end{array}$ & 30 & 35,7 \\
\hline Transdisciplinarity & 12 & 14,3 \\
\hline Other: I do not know & 9 & 10,7 \\
\hline
\end{tabular}


The teachers most often indicated that society 5.0 requires them to be innovative and show unconventional and adaptive thinking $(n=33 ; 39.3 \%)$. They also indicated that society 5.0 requires teachers to be independent and flexible in thinking and acting $(n=$ $30 ; 35.7 \%)$. The least frequently indicated requirement was the capability to learn quickly $(n=8 ; 9.5 \%)$.

Table 9. Relations between gender, age, length of work experience, degree of professional promotion, and competences required of teachers in society 5.0 - Pearson's chi square test

\begin{tabular}{|c|c|c|c|c|}
\hline & $x^{2}$ & $d f$ & $p$ & Cramér's V \\
\hline Gender $\mathrm{x}$ ability to learn quickly & 1,92 & 1 & 0,166 & 0,15 \\
\hline Age $\mathrm{x}$ ability to learn quickly & 7,92 & 3 & 0,048 & 0,31 \\
\hline Work experience $\mathrm{x}$ ability to learn quickly & 5,54 & 4 & 0,236 & 0,26 \\
\hline Professional promotion degree $\mathrm{x}$ ability to learn quickly & 27,16 & 3 & $<0,001$ & 0,57 \\
\hline Gender x innovation & 3,28 & 1 & 0,070 & 0,20 \\
\hline Age $\mathrm{x}$ innovation & 26,88 & 3 & $<0,001$ & 0,57 \\
\hline Work experience $\mathrm{x}$ innovation & 21,75 & 4 & $<0,001$ & 0,51 \\
\hline Professional promotion degree $\mathrm{x}$ innovation & 12,37 & 3 & 0,006 & 0,38 \\
\hline Gender $\mathrm{x}$ readiness for continuous learning & 0,49 & 1 & 0,485 & 0,08 \\
\hline Age $\mathrm{x}$ readiness for continuous learning & 3,35 & 3 & 0,340 & 0,20 \\
\hline Work experience $\mathrm{x}$ readiness for continuous learning & 5,80 & 4 & 0,215 & 0,26 \\
\hline $\begin{array}{l}\text { Professional promotion degree } \mathrm{x} \text { readiness for continu- } \\
\text { ous learning }\end{array}$ & 19,39 & 3 & $<0,001$ & 0,48 \\
\hline Gender $\mathrm{x}$ ability to search for information & 4,30 & 1 & 0,038 & 0,23 \\
\hline Age $\mathrm{x}$ ability to search for information & 41,21 & 3 & $<0,001$ & 0,70 \\
\hline Work experience $\mathrm{x}$ ability to search for information & 40,28 & 4 & $<0,001$ & 0,69 \\
\hline $\begin{array}{l}\text { Professional promotion degree } \mathrm{x} \text { ability to search for } \\
\text { information }\end{array}$ & 22,81 & 3 & $<0,001$ & 0,52 \\
\hline Gender $\mathrm{x}$ independence & 0,15 & 1 & 0,702 & 0,04 \\
\hline Age $\mathrm{x}$ independence & 10,50 & 3 & 0,015 & 0,35 \\
\hline Work experience $\mathrm{x}$ independence & 15,07 & 4 & 0,005 & 0,42 \\
\hline Professional promotion degree $\mathrm{x}$ independence & 24,20 & 3 & $<0,001$ & 0,54 \\
\hline Gender x transdisciplinarity & 3,04 & 1 & 0,081 & 0,19 \\
\hline Age $\mathrm{x}$ transdisciplinarity & 19,69 & 3 & $<0,001$ & 0,48 \\
\hline Work experience $\mathrm{x}$ transdisciplinarity & 18,67 & 4 & $<0,001$ & 0,47 \\
\hline Professional promotion degree $\mathrm{x}$ transdisciplinarity & 6,46 & 3 & 0,091 & 0,28 \\
\hline
\end{tabular}

The analysis of the empirical material showed that women more often than men emphasized that society 5.0 requires teachers to have the ability to learn quickly. The teachers in the middle two age groups were also more likely to advocate the need for fast learning skills.

The teachers aged 36-45 more often than others indicated that society 5.0 requires them to be innovative, unconventional, and adaptive. On the other hand, the teachers from the oldest age group wrote more often than others about the obligation to develop the 
ability to search for reliable and necessary information, analyze and verify it. More often than others, the same group emphasized the importance of independence and flexibility in thinking and acting. Moreover, in the oldest age group, the opinions about the importance of transdisciplinarity in society 5.0 were more often expressed.

Similar relations were observed with regard to the length of work experience. The teachers who worked 11-20 years or 21-30 years more often than others indicated that society 5.0 requires them to be innovative, unconventional, and adaptive. On the other hand, the teachers of the two oldest groups, with the longest work experience, emphasized more often than others imposing on them the requirement to develop the ability to search for reliable and necessary information and to analyze and verify it. The same groups emphasized more often than others the importance of independence and flexibility in thinking and acting. Moreover, in the group of the teachers whose work experience amounted to 21-30 years, the role of transdisciplinarity in society 5.0 was indicated more often.

Dependencies were also observed with regard to the degree of professional promotion. The trainee and appointed teachers wrote more often that society 5.0 required them to have the ability to learn quickly. More often than others, the appointed and diploma teachers spoke about their obligation to develop innovative, unconventional, and adaptive thinking. The appointed teachers, more often than others, also felt that society 5.0 requires them to be ready for continuous learning, and the diploma teachers - the ability to search for reliable and necessary information, analyze and verify it, as well as to be independent and flexible in thinking and acting.

The afterthought on these data allows for a reflection that the respondents' knowledge about the competences required from the teacher by the new type of society is scarce, general, slogan-like. Moreover, it coincides with the ones formulated in the formal and legal documents regulating the work of teachers and schools and pedeutologists' postulates.

\section{Benefits from Realizing the Idea of Society 5.0 as Assessed by the Respondents}

The teachers provided various responses to the question of what benefits can arise from realizing the model of society 5.0. The answers to this question are presented in Table 10.

Table 10. Benefits of implementing the idea of 5.0 society - frequencies

\begin{tabular}{lcc}
\hline Response & $\boldsymbol{n}$ & Percentage \\
\hline Personalization in terms of meeting the needs of every human being & 12 & 14,3 \\
\hline Unlimited learning opportunities & 18 & 21,4 \\
\hline Opportunities to work free from the limitations of time, place, or space & 30 & 35,7 \\
\hline Personalized education & 6 & 7,1 \\
\hline Emergence of new professions & 15 & 17,9 \\
\hline Other: I do not know & 6 & 7,1 \\
\hline
\end{tabular}


The teachers most often expressed the opinion that the implementation of the idea of society 5.0 brings benefits in the form of the possibility of working free from the limitations of time, place, or space $(n=30 ; 35.7 \%)$. They also indicated that society 5.0 is associated with unlimited learning opportunities $(n=18 ; 21.4 \%)$ and the emergence of new professions $(n=15 ; 17.9 \%)$. They also noticed the benefits in the form of personalization in terms of meeting the needs of every human being $(n=12 ; 14.3 \%)$.

Table 11. Relations between gender, age, length of work experience, the degree of professional promotion, and the opinion on the benefits resulting from society 5.0 - Pearson's chi square test

\begin{tabular}{lrrrc}
\hline & $\chi^{2}$ & $d f$ & $p$ & Cramér's $V$ \\
\hline Gender x personalization in meeting the needs & 3,04 & 1 & 0,081 & 0,19 \\
\hline Age x personalization in meeting the needs & 18,67 & 3 & $<0,001$ & 0,47 \\
\hline Work experience x personalization in meeting the needs & 23,62 & 4 & $<0,001$ & 0,53 \\
\hline $\begin{array}{l}\text { Professional promotion degree x personalization in meeting the } \\
\text { needs }\end{array}$ & 24,50 & 3 & $<0,001$ & 0,54 \\
\hline Gender x unlimited learning & 4,98 & 1 & 0,026 & 0,24 \\
\hline Age x unlimited learning & 34,26 & 3 & $<0,001$ & 0,64 \\
\hline Work experience x unlimited learning & 28,21 & 4 & $<0,001$ & 0,58 \\
\hline Professional promotion degree x unlimited learning & 13,90 & 3 & 0,003 & 0,41 \\
\hline Gender x freedom from limitations & 0,15 & 1 & 0,702 & 0,04 \\
\hline Age x freedom from limitations & 3,42 & 3 & 0,331 & 0,20 \\
\hline Work experience x freedom from limitations & 4,67 & 4 & 0,322 & 0,24 \\
\hline Professional promotion degree x freedom from limitations & 2,26 & 3 & 0,520 & 0,16 \\
\hline Gender x personalized education & 1,41 & 1 & 0,236 & 0,13 \\
\hline Age x personalized education & 10,50 & 3 & 0,015 & 0,35 \\
\hline Work experience x personalized education & 2,68 & 4 & 0,613 & 0,18 \\
\hline $\begin{array}{l}\text { Professional promotion degree x personalized } \\
\text { education }\end{array}$ & 8,33 & 3 & 0,040 & 0,32 \\
\hline Gender x emergence of new professions & & & & \\
\hline Age x emergence of new professions & 22,11 & 1 & $<0,001$ & 0,51 \\
\hline Work experience x emergence of new professions & 28,22 & 4 & $<0,001$ & 0,54 \\
\hline $\begin{array}{l}\text { Professional promotion degree x emergence of new } \\
\text { professions }\end{array}$ & 14,33 & 3 & 0,002 & 0,41 \\
\hline
\end{tabular}

The analysis of the collected data allows for the conclusion that women more often than men answered that the benefit of society 5.0 is the possibility of unlimited learning and the emergence of new professions. The age group of $36-45$ more often indicated in relation to the remaining ones an advantage in the form of emerging new professions.

Two middle-aged groups emphasized more often than others that the benefit of realizing the idea of society 5.0 is personalization in terms of satisfying the needs of every human 
being. More often than others, the oldest age group marked the benefits in the form of unlimited learning and personalized education.

The respondents with 5-10 years of work experience more often than others emphasized the benefits of personalization in terms of meeting the needs of every human being, while the respondents with 21-30 years of work experience - the possibility of unlimited learning. In the 11-20-year-old group, the emergence of new professions was more often indicated as a benefit coming from society 5.0.

The contract and appointed teachers responded more often than others that society 5.0 had the benefit of personalization in terms of meeting needs and the emergence of new professions. The diploma teachers, more often than others, indicated unlimited learning opportunities and personalized education.

Therefore, it can be noticed that the most frequently perceived benefits in creating a new model of society are perceived by the respondents in the possibility of full, individualized satisfaction of needs and unlimited learning and work opportunities. Such an image of society was defined not so much based on knowledge or even a certain reflection on a new concept of society but personal desires and ideas of the respondents.

\section{Threats Resulting from the Implementation of the Idea of Society 5.0 in the Opinion of the Respondents}

The teachers provided various responses to the question about the risks of implementing the idea of society 5.0. The answers to this question are presented in Table 12.

Table 12. Threats resulting from the idea of society 5.0 - frequencies

\begin{tabular}{lcc}
\hline Response & $n$ & Percentage \\
\hline Growing alienation of people & 24 & 28,6 \\
\hline Increase in unemployment & 9 & 10,7 \\
\hline Human's addiction to technology & 36 & 42,9 \\
\hline $\begin{array}{l}\text { Increase in addiction (alcoholism, drug addiction, addiction to gambling, } \\
\text { Internet, etc.) }\end{array}$ & 17 & 20,2 \\
\hline Psychological and emotional crises & 9 & 10,7 \\
\hline Replacement of direct education with the media-interposed one & 33 & 39,3 \\
\hline $\begin{array}{l}\text { Replacing social contacts in the real world by contacts in the virtual } \\
\text { world }\end{array}$ & 30 & 35,7 \\
\hline
\end{tabular}

The teachers most often indicated that the idea of society 5.0 carries risks in the form of human dependence on technology $(n=36 ; 42.9 \%)$, replacing direct education interposed by the media $(n=33 ; 39.3 \%)$, replacing social contacts in the real world through contacts in the virtual world $(n=30 ; 35.7 \%)$ and increasing alienation of people $(\mathrm{n}=24 ; 28.6 \%)$. 
Table 13. Relations between gender, age, length of work experience and the degree of professional promotion and opinions about threats stemming from the idea of society 5.0 - Pearson's chi square test

\begin{tabular}{|c|c|c|c|c|}
\hline & $\chi^{2}$ & $d f$ & $p$ & Cramér's V \\
\hline Gender $\mathrm{x}$ alienation & 0,66 & 1 & 0,417 & 0,09 \\
\hline Age $\mathrm{x}$ alienation & 6,21 & 3 & 0,102 & 0,26 \\
\hline Work experience $\mathrm{x}$ alienation & 12,58 & 4 & 0,014 & 0,39 \\
\hline Professional promotion degree $\mathrm{x}$ alienation & 10,18 & 3 & 0,017 & 0,35 \\
\hline Gender x unemployment & 1,65 & 1 & 0,200 & 0,14 \\
\hline Age $\mathrm{x}$ unemployment & 23,89 & 3 & $<0,001$ & 0,47 \\
\hline Work experience $\mathrm{x}$ unemployment & 11,78 & 4 & 0,019 & 0,34 \\
\hline Professional promotion degree $\mathrm{x}$ unemployment & 23,69 & 3 & $<0,001$ & 0,53 \\
\hline Gender $\mathrm{x}$ technology addiction & 2,19 & 1 & 0,139 & 0,16 \\
\hline Age $\mathrm{x}$ technology addiction & 6,93 & 3 & 0,074 & 0,28 \\
\hline Work experience $\mathrm{x}$ technology addiction & 12,70 & 4 & 0,013 & 0,39 \\
\hline Professional promotion degree $\mathrm{x}$ technology addiction & 17,74 & 3 & $<0,001$ & 0,46 \\
\hline Gender $\mathrm{x}$ addictions in general & 17,1 & 1 & $<0,001$ & 0,46 \\
\hline Age $\mathrm{x}$ addictions in general & 28,42 & 3 & $<0,001$ & 0,50 \\
\hline Work experience $\mathrm{x}$ addictions in general & 32,94 & 4 & $<0,001$ & 0,46 \\
\hline Professional promotion degree $\mathrm{x}$ addictions in general & 10,37 & 3 & 0,016 & 0,35 \\
\hline Gender $\mathrm{x}$ crises & 2,19 & 1 & 0,139 & 0,16 \\
\hline Age $\mathrm{x}$ crises & 25,20 & 3 & $<0,001$ & 0,55 \\
\hline Work experience $\mathrm{x}$ crises & 35,22 & 4 & $<0,001$ & 0,65 \\
\hline Professional promotion degree $\mathrm{x}$ crises & 11,63 & 3 & 0,009 & 0,37 \\
\hline Gender $x$ replacing education with the media & 2,85 & 1 & 0,092 & 0,18 \\
\hline Age $\mathrm{x}$ replacing education with the media & 20,59 & 3 & $<0,001$ & 0,50 \\
\hline Work experience $\mathrm{x}$ replacing education with the media & 10,79 & 4 & 0,029 & 0,36 \\
\hline $\begin{array}{l}\text { Professional promotion degree } \mathrm{x} \text { replacing education with the } \\
\text { media }\end{array}$ & 3,39 & 3 & 0,336 & 0,20 \\
\hline Gender $\mathrm{x}$ replacement of real contacts & 1,96 & 1 & 0,161 & 0,15 \\
\hline Age $\mathrm{x}$ replacement of real contacts & 27,92 & 3 & $<0,001$ & 0,58 \\
\hline Work experience $\mathrm{x}$ replacement of real contacts & 36,19 & 4 & $<0,001$ & 0,66 \\
\hline Professional promotion degree $\mathrm{x}$ replacement of real contacts & 9,55 & 3 & 0,023 & 0,34 \\
\hline
\end{tabular}

The analysis allows the conclusion that men more often than women saw the risks of the increase in addictions.

The persons aged 25-35 more often than other respondents noticed a threat in the form of an increase in unemployment (while the least frequently - compared to other groups - they pointed to the risk of replacing real contacts with virtual ones), and in the 36-45 age group - to an increase in addictions. More often than others, the oldest respondents saw the threats of psychological crises and the replacement of direct education by the media-interposed one. 
More often than others, the respondents with the shortest and the most extended work experience emphasized the dangers of increasing alienation. The respondents with 5-10 years and 11-20 years of work experience more often than others indicated unemployment, the increase in addiction as a potential threat from the idea of community 5.0, replacing direct education interposed by the media and interpersonal contacts - with virtual relationships. More often than others, the respondents with the most extended work experience indicated addiction to technology and psychological crises.

The trainee and appointed teachers more often than others saw a threat of increasing alienation, increasing addictions, and replacing real contacts with virtual ones, and the contract ones - of increasing unemployment. The diploma teachers saw the threat of technology addiction and psychological crises more often than others.

\section{The Role of the Teacher and School in Society 5.0. in the Opinions of the Respondents}

Responses to this question about the role of the teacher and school in society 5.0 are presented in Table 14.

Table 14. The role of school and teachers in society $5.0-$ frequencies

\begin{tabular}{lcc}
\hline Response & $\boldsymbol{n}$ & Percentage \\
\hline Teach how to use technology & 9 & 10,7 \\
\hline Shape competences that prepare for life & 30 & 35,7 \\
\hline Have digital competences & 45 & 53,6 \\
\hline
\end{tabular}

More than a half, $53.6 \%$ of the teachers expressed the opinion that the role of schools and teachers in the 5.0 society is to train students' digital competences. The least frequent, because only $10.7 \%$ of the surveyed teachers believed that the role of schools and teachers is to prepare students to use modern technologies.

Table 15. Relations between gender, age, length of work experience, degree of professional promotion, and views on the role of school and teachers in society 5.0 - Pearson's chi square test

\begin{tabular}{lrrrr}
\hline & $\chi^{2}$ & $d f$ & $p$ & Cramér's $\boldsymbol{V}$ \\
\hline Gender x role of school and teachers & 8,33 & 2 & 0,016 & 0,32 \\
\hline Age x role of school and teachers & 20,18 & 6 & 0,003 & 0,35 \\
\hline Work experience x role of school and teachers & 41,26 & 8 & $<0,001$ & 0,50 \\
\hline Professional promotion degree x role of school and teachers & 38,67 & 6 & $<0,001$ & 0,48 \\
\hline
\end{tabular}

These responses were related to gender, age, length of work experience, and the degree of professional promotion (Table 15). 
Women more often indicated that schools and teachers should teach how to use technology, while men - that schools and teachers should develop competences preparing for life and possess digital competences.

Similarly, the respondents from the two oldest age groups and those under 25 were of a similar opinion, while those aged 25-35 believed that schools should teach the use of technology.

The views on the role of the school were also related to the length of work experience and the degree of professional promotion - the respondents from the two oldest groups and the diploma teachers more often believed that the school should prepare for life; with the shortest work experience, and the contract teachers - that it should shape the digital competences of students.

The results of the research have shown that teachers are afraid that in the light of the possibilities created by virtual reality, there may be unfavorable changes in the perception of a human being as a defective being, unable to cope independently without the support of modern technologies and the deepening of fears of the ongoing changes implied by radically declining self-esteem of individuals, i.e., a deficit of self-confidence, losing faith in one's strength, declining belief that everyone is valuable and deserves the right to happiness, to satisfy one's desires and dreams. In this "melting pot of uncertainty and opportunities", teachers see themselves as personal tutors/coaches who will direct the attention and motivation of their students to implement basic practices that guarantee individuals the full exercise of cardinal human rights to freedom and self-determination. These include activities related to arousing and maintaining the willingness to constantly learn, questioning new information, equipping the student with the ability to think critically, protecting against unreflective assumption of other people's views and beliefs, giving the opportunity to notice errors in thinking patterns and procedures and create new operational knowledge (the practice of conscious living).

\section{Conclusions}

The research presented in this text is only the first pilot element of extensive explorations conducted within one of the priority research areas of the Silesian University of Technology - Processes Automation and Industry 4.0. in terms of the socio-cultural and methodological implications of Industry 4.0. hence the collected material does not allow for the formulation of methodologically legitimate conclusions but may constitute a stimulus for further research and discussion on the problem, bearing in mind that the next step in social evolution becomes a fact.

In line with the vision of the creators of the concept of society 5.0. it requires the awareness of its citizens both at the stage of its creation and at the stage of using the opportunities it creates. The mentioned awareness and competences allowing the use of the generated by Industry 4.0. goods that offer a possibility of satisfaction of individual needs are to be 
shaped by the school. Therefore, its role and the role of the teacher will be transformed in all spheres of functioning. The durability of these changes requires from teachers not only their full acceptance but also the commitment to their implementation and creation. The research results are not optimistic. Residual, superficial knowledge of teachers about "in statu nascendi" society 5.0 based on general information provided by the media does not allow for providing even fragmentary answers to the detailed questions posed in the research. On the other hand, it is a cardinal argument that justifies the need to start work on preparing and implementing rational support programmes for teachers as soon as possible so that they can fully consciously and responsibly fulfill their professional role assigned by the new society.

\section{References:}

Tworóg, J., \& Mieczkowski, P.(2019). Krótka opowieść o społeczeństwie 5.0. czyli jak żyć i funkcjonować $w$ dobie gospodarki 4.0. i sieci 5G. Wydawnictwo Fundacja Digital Poland.

Kiepas, A. (2020). Człowiek w świecie procesów cyfryzacji - współczesne wyzwania i przyszłe skutki. Filozofia i Nauka. Studia filozoficzne i interdyscyplinarne, 8(1), 155-174. https://doi.org/10.37240/ FiN.2020.8.1.6

Harayama, Y. (2017). Society 5.0: Aiming for a New Human-Centered Society. Collaborative Creation through Global R\&D Open Innovation for Creating the Future. Hitachi Review, 66(6), 554-555.

Polski Komitet ds. UNESCO. (2015). Agenda na rzecz Zrównoważonego Rozwoju 2030. https://www. gov.pl/web/rozwoj-praca-technologia/agenda-2030

du Vall, M. (2019). Super inteligentne społeczeństwo skoncentrowane na ludziach czyli o idei społeczeństwa 5.0 słów kilka. Państwo i Społeczeństwo, 2, 11-31.https://doi.org/10.34697/2451-0858-pis-2019-2-001 Wojciszke, B. (2000). Postawy i ich zmiana. In J.Strelau (Ed.), Psychologia, vol.3, Jednostka w spoleczeństwie i elementy psychologii stosowanej (pp. 79-105). Gdańskie Wydawnictwo Psychologiczne.

Wojciszke, B. (2011). Psychologia społeczna. Wydawnictwo Naukowe Scholar.

Zimbardo, P.G. (1999). Psychologia $i$ życie. Wydawnictwo Naukowe PWN. 
